\title{
UPAYA MENINGKTKAN KETERAMPILAN PROSES SISWA MELALUI PENDEKATAN SAVI PADA MATERI REDOKS KELAS $X$
}

\author{
A.D. Susilo. R. Slamet. Dan Marheni.
}

Jurusan Kimia, Fakultas MIPA, Universitas Negeri Jakarta, Jl. Pemuda No. 10 Rawamangun Jakarta 13220, Indonesia

Korespondensi Penulis: ahmaddwisusilo@gmail.com

\begin{abstract}
Abstrak
Tujuan penelitian ini adalah menerapakan Pendekatan SAVI untuk meningkatkan keterampilan proses siswa. Penelitian ini dilakukan melalui penelitian tindakan kelas yang terdiri dari perencanaan, tindakan, pengamatan, evaluasi dan refleksi. Subjek penelitian adalah siswa kelas X SMAN 52 Jakarta. Indikator keberhasilan pada penelitian ini adalah $\geq 70 \%$ untuk setiap indikator keterampilan proses sains. Berdasarkan hasil penelitian dan pembahasan rata-rata persentase hasil tes keterampilan proses sains siswa pada siklus pertama adalah 55,73 dan hanya 1 indikator tercapai. Pada siklus kedua, semua indikator sudah tercapai dengan rata-rata persentase keterampilan proses sains 74,36 , sedangkan rata-rata persentase peningkatan aktivitas siswa melalui observasi yaitu dari 61,55 pada siklus I menjadi 76,24 pada siklus II. Peningkatan ini diperoleh dengan cara melibatkan siswa secara aktif dalam kegiatan diskusi, presentasi secara berkelompok dan memfasilitasi semua gaya belajar siswa.
\end{abstract}

\section{Kata Kunci:}

Keterampilan Proses, Pendekatan SAVI, Penelitian Tindakan Kelas.

\begin{abstract}
Curriculum had been stressed that learning on chemistry should be attaintmen of competency achievement through scientific process. The process learning on chemistry is promised can take developing of process skill, understanding of concept, application of concept, scientific attitude, and the activities of chemistry base on the issues is developing in society. In fact, learning on chemistry less more developt science process skill. This study aims to improve science process skill through SAVI Approaching. Research method is used classroom action research. Test and observation form is used to instrument. The subject of research are secondary students' grade $X$ in SMAN 52 Jakarta. The intended success indicator was that at $\geq 70 \%$ of each indicator science proces skills. The result shown average of the percentage results of science proces skills test in the first cycle was 55,73 and only one indicator has been achieved. In the second cycle, all the indicators have been achieved with average of percentage science proces skills 74,36. Whereas average of the percentage enhanching student activity through observation is 61,55 at first cycle become 76,24 at second cycle. Enhanching the student activity acquired by engage of student to active in discussion, presentation and facilitation of student learning style.
\end{abstract}

\section{Keywords:}

Science Process Skill, SAVI Approaching, Classroom Action Research.

\section{Pendahuluan}

Kimia sebagai salah satu cabang sains yang diajarkan oleh guru kepada siswa ditingkat SMA merupakan ilmu pengetahuan dasar yang terdiri dari dua hal yang tidak terpisahkan, yaitu kimia sebagai produk (pengetahuan deklaratif yang berupa fakta, konsep, prinsip, hukum, dan teori temuan ilmuwan) dan kimia sebagai proses (pengetahuan prosedural/kerja ilmiah) [1]. Keterampilan proses sains adalah keterampilan berpikir (thingking skills) yang digunakan seseorang dalam melakukan penyelidikan ilmiah [2]. Keterampilan proses dapat dilatih dalam proses pembelajaran sains [3]. Namun demikian, pembelajaran sains termasuk kimia pada umumnya masih berorientasi pada teacher centered [4]. Guru masih banyak yang menggunakan metode tradisional dalam proses pembelajaran (ceramah) [5]. Berdasarkan hasil penelitian yang dilakukan oleh William Foulds di Western 
Australia [6] didapatkan bahwa keterampilan proses sains siswa masih belum berkembang. Hal ini dikarenakan oleh kurangnya pengajaran oleh guru sains tentang keterampilan siswa dalam laboratorium.

Berdasarkan hasil angket pendahuluan dan wawancara guru menunjukkan bahwa sebanyak 52,5\% pembelajaran kimia masih didominasi dengan ceramah. Namun, siswa lebih tertarik belajar kimia jika mereka mendapatkan pengalaman yang menarik menggunakan semua panca indera mereka, tidak hanya melihat dan mendengarkan saja [7]. Hal ini ditunjukkan dari hasil angket sebanyak $77,5 \%$ tertarik jika pembelajaran kimia dengan media yang variatif dan $100 \%$ siswa senang melakukan praktikum di laboratorium. Berdasaran pada hasil tes keterampilan proses sains siswa di awal penelitian, nilai rata-rata yang diperoleh hanyalah 49,91\%. Hasil ini menunjukkan bahwa keterampilan proses sains siswa kelas $X$ rendah, sehingga masih perlu ditingkatkan.

Proses pembelajaran siswa harus dikembangkan dan ditingkatkan dengan berbagai inovasi dan kreatifitas guru dengan pendekatan pembelajaran yang sesuai dengan karakteristik siswa dan materi [4] Begitu juga evaluasi yang dilakukan juga harus sesuai dengan tujuan pembelajaran atau indikator yang telah ditetapkan secara menyeluruh. Artinya, alat evaluasi yang digunakan dapat mengukur tingkat kemajuan belajar siswa, tidak hanya menyangkut evaluasi dengan tes, tetapi juga penilaian proses belajar siswa yang menyangkut keterampilan siswa dalam proses pembelajaran tersebut [8].

Pendekatan SAVI (Somatis, Auditori, Visual dan Intelektual) dapat digunakan sebagai upaya untuk mengembangkan kemampuan penalaran, keterampilan proses dan kemampuan intelektual siswa dengan menerapkan potensi yang dimilikinya yang meliputi pikiran dan semua indera pada saat yang bersamaan [9]. Pendekatan SAVI penting dalam proses pembelajaran. Alasannya, pendekatan SAVI memiliki unsur somatis, auditori, visual dan intelektual. Pendekatan ini menggabungkan gerakan fisik dengan aktivitas intelektual dan penggunaan semua indera yang berpengaruh dalam proses pembelajaran, jika dioptimalkan secara sinergi dapat mendukung terciptanya belajar aktif [9]. Hal ini didukung oleh hasil angket gaya belajar siswa, yang menunjukkan bahwa dalam satu kelas terdapat berbagai jenis gaya belajar, yaitu gaya belajar somatis, auditori dan visual. Angket gaya belajar siswa mengacu pada Barsch Learning Style inventory yang telah divalidasi [10].

Melalui pendekatan SAVI diharapkan keterlibatan siswa dalam pembelajaran menjadi optimal sehingga pemerolehan hasil belajarnya pun maksimal [11]. Metode yang digunakan adalah demonstrasi, praktikum dan diskusi kelompok [12].

Berdasarkan uraian diatas, maka Pendekatan SAVI digunakan untuk meningkatkan keterampilan proses siswa pada materi redoks.

\section{Metodologi Penelitian}

Penelitian ini dilaksanakan di SMA Negeri 52 Jakarta. Subjek penelitian adalah siswa kelas X pada tahun ajaran 2011/2012. Penelitian ini dilaksanakan pada November 2011-Mei 2012. Fokus penelitian tindakan ini adalah peningkatan keterampilan proses sains siswa. Proses pembelajaran dilakukan dengan pendekatan SAVI.

Indikator penelitian yang digunakan adalah lima indikator keterampilan proses yang dikemukakan oleh American Association for The Advancement of Science yaitu keterampilan mengamati, mengklasifikasi, menafsirkan, menerapkan dan mengkomunikasikan [3]. Penelitian ini dikatakan berhasil apabila ketercapaian masing-masing indikator penelitian $\geq 70 \%$ 
Gambar 1: Grafik Hasil Ketercapaian Indikator Keterampilan Proses Siswa Setiap Indikator Pada Tes di Awal Penelitian, Tes Akhir Siklus I, Dan Tes Akhir Siklus II

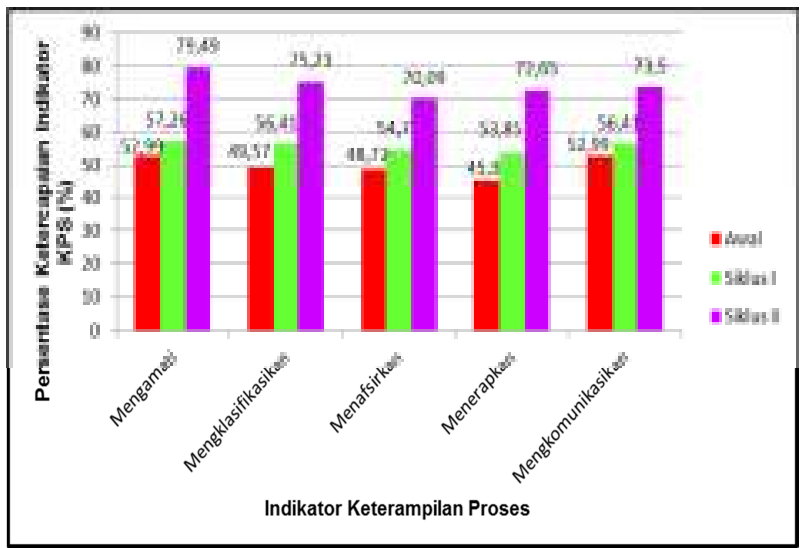

yang mengacu pada rubrik keterampilan proses siswa [13].

Sumber data yang digunakan dalam penelitian adalah guru dan siswa kelas $X$ semester genap SMA Negeri 52 Jakarta, serta lingkungan yang mendukung pelaksanaan kegiatan pembelajaran. Jenis data yang digunakan adalah data hasil observasi pembelajaran awal (sebelum penelitian), data hasil angket siswa pada analisis pendahuluan, data hasil wawancara dengan guru, data hasil tes keterampilan proses siswa di awal penelitian, data hasil tes keterampilan proses siswa setelah diberi perlakuan (akhir siklus), data hasil observasi proses pembelajaran dan data hasil kuesioner siswa akhir siklus. Data hasil keterampilan proses siswa diperoleh dari memberikan soal tes keterampilan proses siswa setiap akhir siklus. Data hasil observasi diperoleh dari laporan pengamatan lima orang observer. Data hasil angket siswa diperoleh dengan cara memberikan kuesioner kepada siswa setiap akhir siklus.

Penelitian ini dilakukan melalui penelitian tindakan kelas yang terdiri dari perencanaan, tindakan, pengamatan, evaluasi dan refleksi [14] Pelaksanaan penelitian tindakan kelas ini terdiri dari dua siklus [14]. Setiap siklus dikerjakan sesuai dengan hasil evaluasi dan refleksi pada siklus sebelumnya. Analisis pendahuluan digunakan untuk mengetahui masalah-masalah yang ada dalam proses pembelajaran [14]. Analisis pendahuluan dilakukan melalui wawancara guru, pengisian kuesioner oleh siswa, dan tes keterampilan proses siswa di awal penelitian. Selanjutnya, guru dan peneliti mendiskusikan tindakantindakan yang tepat untuk menyelesaikan masalah pembelajaran. Berdasarkan hasil analisis pendahuluan, disimpulkan penelitian tindakan kelas dengan prosedur sebagai berikut:

\section{Tahap Perencanaan}

Tahap perencanaan didiskusikan dengan guru kimia di sekolah untuk mencari solusi dari masalah-masalah yang terjadi dalam proses pembelajaran di kelas. Perencanaan tindakan ini meliputi pembuatan RPP dengan pendekatan SAVI, membentuk kelompok siswa berdasarkan gaya belajar siswa yang beragam, membuat lembar observasi pembelajaran dan catatan lapangan bebas, membuat angket siswa setiap akhir siklus, dan membuat tes keterampilan proses akhir siklus.

\section{Tahap Pelaksanaan Tindakan}

Tahap pelaksanaan tindakan berupa pelaksanaan skenario pembelajaran yang telah direncanakan. Pada tahap apresepsi dan motivasi guru memberikan pertanyaan yang berhubungan dengan reaksi redoks, bilangan oksidasi, reduktor-oksidator dan meminta siswa menyebutkan peristiwa redoks yang terjadi dalam kehidupan.Siswa mengeksplorasi pengetahuannya dengan sumber belajar dan fasilitas yang ada, mengoptimalkan gaya belajarnya sehingga diperoleh konsep materi pembelajaran melalui metode praktikum, demonstrasi, dan diskusi. Siswa mempresentasikan hasil diskusi kelompok di depan kelas dan akan diperoleh kesimpulan pada tahap elaborasi dan memperluas pemahaman siswa melalui latihan soal dan 
Gambar 2 : Grafik Persentase Peningkatan Keterampilan Proses Siswa Melalui Observasi padaSiklus I dan Siklus II

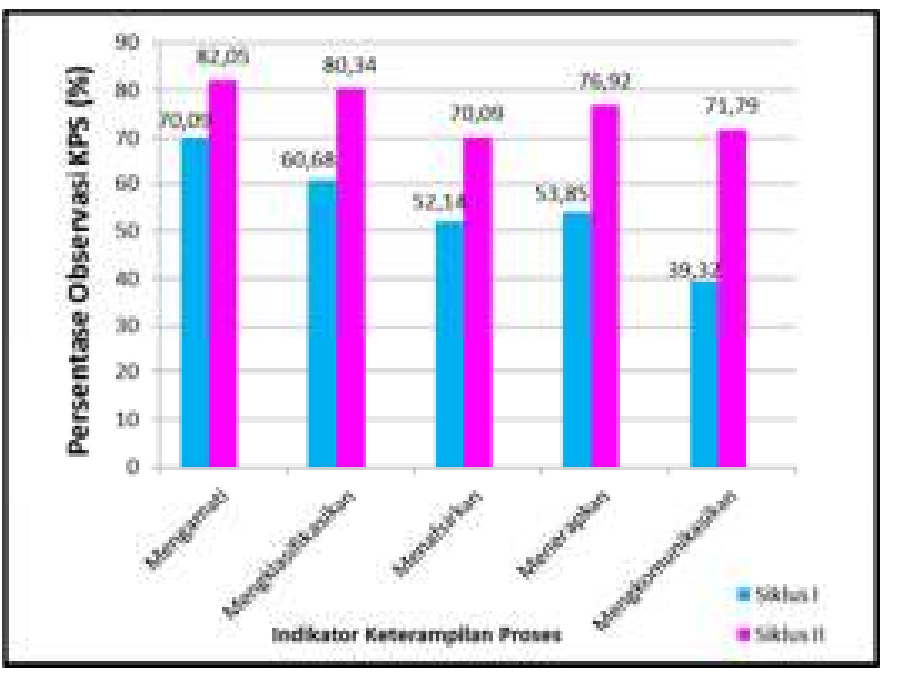

tanya jawab pada tahap konfirmasi. Proses pelaksanaan tindakan diamati observer yang mencatat semua kegiatan yang dilakukan oleh guru dan siswa dalam proses pembelajaran dan menilai keterampilan proses siswa berdasarkan observasi. Pada setiap akhir siklus dilakukan tes keterampilan proses siswa untuk mengetahui peningkatan keterampilan proses siswa.

\section{Tahap Pengamatan}

Tahap pengamatan dilaksanakan oleh lima observer. Yang diamati adalah hal-hal yang terjadi selama proses pembelajaran, meliputi diskusi kelompok, presentasi, tanya-jawab dan pertanyaan-pertanyaan yang muncul selama proses pembelajaran. Pengamatan tersebut termasuk ke dalam penggunaan aspek audio, visual dan somatik siswa. Hasil pengamatan berupa penilaian keterampilan proses siswa dengan lembar observasi dan catatan lapangan.

\section{Tahap Evaluasi dan Refleksi}

Tahap evaluasi dan refleksi dilakukan dengan menganalisis hasil pengamatan yang berupa hasil penilaian keterampilan proses siswa berdasarkan observasi, tes keterampilan proses siswa, catatan lapangan, dan angket siswa. Tujuanya adalah untuk mengetahui ketercapaian dan kekurangan dari tindakan yang dilakukan Hasil refleksi berupa catatan keberhasilan dan kegagalan pelaksanaan tindakan sesuai dengan rencana yang telah dibuat [16]. Apabila indikator-indikator penelitian belum tercapai maka akan dilakukan siklus berikutnya hingga indikator keberhasilan tercapai [16].

Data hasil penelitian tindakan kelas dianalisis setelah proses pembelajaran. Data ini diolah secara kualitatif dan kuantitatif. Data yang diperoleh kemudian diambil kesimpulan.

\section{Hasil dan Pembahasan}

\section{Hasil Analisis Pendahuluan}

Berdasarkan wawancara guru dan angket siswa, diperoleh data bahwa siswa kurang memahami materi tentang redoks. Hasil angket siswa menunjukkan rendahnya aktivitas siswa dalam proses pembelajaran terkait dengan keterampilan proses siswa dalam pembelajaran. Hal ini diperkuat dengan hasil tes keterampilan proses siswa di awal penelitian. Tes awal dilakukan untuk mengetahui keterampilan proses siswa sebelum dilakukan penelitian. Dari tes awal ini, diperoleh persentase rata-rata hasil keterampilan proses siswa adalah 49,91. Hal ini berarti keterampilan proses siswa masih rendah.

\section{Hasil Siklus I}

\section{a. Perencanaan}

Dari hasil analisis pendahuluan, maka direncanakan suatu tindakan yang sebagai solusi untuk menyelesaikan masalah-masalah yang ada di kelas. Masalah dalam proses pembelajaran adalah rendahnya keterampilan proses siswa kelas $\mathrm{X}$ dalam hal mengamati, menafsirkan, menerapkan konsep dan mengkomunikasikan. Oleh karena itu, proses pembelajaran dilakukan dengan pendekatan 
SAVI sebagai alternatif untuk meningkatkan keterampilan proses siswa.

b. Pelaksanaan tindakan

Pada awal pelaksanaan tindakan, guru menjelaskan tujuan pembelajaran dan memberikan pertanyaan awal untuk mengetahui pemahaman siswa terhadap konsep yang telah dipelajari. Guru memberikan pertanyaan tentang hal yang berhubungan dengan reaksi redoks (reaksi redoks yang dijumpai dalam kehidupan seharihari). Pendekatan pembelajaran yang dilakukan adalah demonstrasi, diskusi, dan tanya-jawab. Pada pembelajaran ini, siswa yang merumuskan konsep pembelajaran sendiri. Guru berperan sebagai fasilitator yang membimbing, mengawasi, dan mengarahkan siswa untuk merumuskan konsep redoks. Selanjutnya, siswa bekerja sama dalam kelompok untuk merumuskan konsep reaksi reduksi-oksidasi. Masing-masing kelompok terdiri dari siswa yang memiliki gaya belajar yang berbeda-beda. Hal ini bertujuan agar siswa yang telah menguasai konsep redosk dapat membimbing teman yang mengalami kesulitan dan saling melengkapi dalam pembelajaran. Selanjutnya, salah satu kelompok memaparkan hasil diskusinya agar kelompok lain dapat menanggapi pendapat kelompok penyaji.

\section{c. Pengamatan}

Pada pengamatan dalam pelaksanaan pembelajaran, diskusi siswa kurang interaktif karena siswa banyak yang hanya diam mendengarkan presentasi kelompok penyaji tanpa memberikan tanggapan dan bertanya. Selain itu siswa masih bergantung pada teman yang dianggap pandai karena siswa yang lain kurang memahami materi. Hal tersebut karena siswa belum terbiasa dengan pendekatan pembelajaran yang dilakukan oleh guru dengan metode demonstrasi yang dilanjut dengan diskusi kelompok dan diskusi kelas.
Selain itu siswa masih malu dalam mengungkapkan tanggapan/pendapat dan menganggap bahwa pendapatnya salah. Guru kurang memotivasi siswa dalam pembelajaran.

\section{d. Evaluasi dan Refleksi}

Berdasarkan hasil observasi penilaian keterampilan proses siswa pada siklus I menunjukkan bahwa persentase keterampilan mengamati 70,09\%, mengklasifikasikan $60,68 \%$, menafsirkan 52,14\%, menerapkan 53,85\%, mengkomunikasikan 39,32\%. Sehingga terdapat 4 indikator penelitian belum tercapai.

Siswa masih belum aktif dalam menanggapi, bertanya dan menjawab pertanyaan guru pada proses pembelajaran. Siswa masih terlihat ragu dalam mengkomunikasikan hasil diskusi, dan mengungkapkan dengan kalimat yang panjang. Dalam kelompok, siswa lain mengandalkan satu orang siswa sebagai pembicara. Siswa juga masih bingung dalam menyimpulkan hasil diskusi.

Berdasarkan hasil tes keterampilan proses pada siklus pertama diperoleh persentase rata-rata hasil keterampilan proses siswa adalah 64,1 . Hal tersebut menunjukkan bahwa tes keterampilan proses pada siklus pertama lebih tinggi dibandingkan dengan tes keterampilan proses siswa di awal penelitian. Namun belum memenuhi indikator keberhasilan yang ditetapkan.

Secara umum, siswa belum aktif menggunakan semua panca inderanya pada proses pembelajaran. Terlihat bahwa hanya indikator mengamati yang berhasil, menandakan bahwa secara umum siswa masih dominan menggunakan aspek audio-visualnya dalam pembelajaran dan belum menggunakan aspek somatik dan intelektualnya secara maksimal, sehingga masih ada empat indikator yang belum berhasil. Gaya belajar siswa belum terfasilitasi dengan optimal. Persentase rata- 
rata setiap indikator memperlihatkan keterampilan proses siswa masih kurang.

\section{Hasil Siklus II}

\section{a. Perencanaan}

Berdasarkan hasil evaluasi dan refleksi pada siklus I, indikator-indikator keterampilan proses yang belum tercapai adalah mengklasifikasikan, menafsirkan, menerapkan dan mengkomunikasikan. Kekurangankekurangan dalam proses pembelajaran adalah kurangnya untuk menyimpulkan hasil pengamatan atau diskusi, kurangnya analisis siswa terhadap penyelesaian soal dengan menerapkan konsep yang telah dipelajari serta kurangnya rasa percaya diri siswa dalam mengemukakan pendapat sehingga siswa masih bergantung kepada temannya yang pandai.

Upaya perbaikan dilakukan dengan cara membuat perencanaan pelaksanaan pembelajaran ulang dengan pendekatan SAVI dengan metode praktikum dan diskusi, guru lebih mengefektifkan lagi proses pembelajaran di kelas dengan lebih fokus pada siswa yang kurang aktif dalam proses diskusi terutama pada proses perumusan konsep.

Guru berperan sebagai fasilitator untuk memberikan pertanyaan motivasi terhadap siswa yang kurang aktif. Siswa diberi motivasi untuk berani mengungkapkan pendapat atau tanggapannya baik dalam diskusi maupun ketika diberi pertanyaan, siswa dilatih dengan pertanyaan yang sesuai dengan tipe soal keterampilan proses (tipe analisis yang bertahap) untuk membiasakan siswa menganalisis dan membuat suatu kesimpulan, guru memberi tahu materi yang akan dipelajari pada pertemuan berikutnya. Pada siklus II ini diharapkan semua siswa aktif bekerja secara mandiri maupun dalam kelompok.

b. Pelaksanaan tindakan
Proses pembelajaran yang dilakukan pada siklus II ini dilakukan dengan metode diskusi dan praktikum. Lembar observasi keterampilan proses yang digunakan pada tahap ini disesuaikan dengan kegiatan pembelajaran yang dilakukan. Pokok bahasan pada siklus ini adalah reaksi disproporsionasi dan aplikasi reaksi redoks.

Pada siklus ini, keaktifan siswa dalam mengemukakan pendapat meningkat akibat dari pemberian motivasi dan fokus guru pada siswa yang belum aktif pada siklus I. Siswa mulai terbiasa dengan metode diskusi dalam pembelajaran yang dilakukan guru. Pada siklus ini sebagian besar siswa sudah dapat bekerja secara mandiri dan kelompok, berani dalam mengemukakan pendapat, membuat kesimpulan, dan menerapkan konsep yang telah dipelajari dalam menyelesaikan soal.

\section{c. Pengamatan}

Berdasarkan hasil observasi dan tes yang dilakukan dapat diketahui bahwa pembelajaran dengan pendekatan SAVI dapat meningkatkan keterampilan proses siswa. Persentase rata-rata hasil tes keterampilan proses siswa pada siklus kedua adalah 74,19. Sedangkan persentase penilaian keterampilan proses berdasarkan observasi adalah 76,24. Perbandingan ketercapaian indikator pada siklus I dan siklus II berdasarkan observasi dapat dilihat pada Gambar 2. Seluruh indikator penelitian telah tercapai.

\section{d. Evaluasi dan Refleksi}

Keterampilan proses siswa meningkat berdasarkan hasil observasi dan hasil tes keterampilan proses siswa. Semua indikator penelitian telah tercapai.

Secara umum tujuan penelitian ini telah tercapai. Keterampilan proses siswa siswa meningkat setelah dilakukan penelitian. Metode pembelajaran dengan kelompok menuntut siswa untuk lebih aktif dan lebih 
menerima tantangan tugas. Hal ini menempatkan siswa untuk berusaha belajar lebih aktif. Keterlibatan siswa dalam proses pembelajaran yang aktif ini mengantarkan siswa pada pemahaman yang lebih baik serta memotivasi siswa untuk aktif dalam proses diskusi. Guru telah memfasilitasi gaya belajar siswa dengan baik.

\section{Kesimpulan dan saran}

\section{Kesimpulan}

Berdasarkan hasil penelitian dan pembahasan yang dilakukan di SMA N 52 Jakarta pada kelas $X$, dapat disimpulkan bahwa; a) pendekatan SAVI dapat meningkatkan keterampilan proses siswa pada materi redoks, b) pendekatan SAVI mengoptimalkan seluruh potensi siswa melalui penggunaan panca inderanya pada proses pembelajaran baik dalam diskusi maupun praktikum.

Berdasarkan hasil tes dan observasi keterampilan proses siswa menunjukkan peningkatan keterampilan proses siswa dari siklus I ke siklus II dan tercapainya semua indikator penelitian. Rata-rata persentase hasil tes keterampilan proses siswa meningkat dari 55,73 pada siklus I menjadi 74,36 pada siklus II, sedangkan rata-rata persentase peningkatan aktivitas siswa melalui observasi yaitu dari 61,55 pada siklus I menjadi 76,24 pada siklus II. Peningkatan ini diperoleh dengan cara melibatkan siswa secara aktif dalam kegiatan diskusi dan presentasi secara berkelompok.

\section{Saran}

Meskipun keterampilan proses sains siswa telah meningkat tetapi masih ada yang harus diperhatikan yaitu sebagai berikut:

1. Peningkatkan keterampilan proses sains siswa dapat dilakukan dengan menerapkan berbagai pendekatan atau metode pembelajaran yang lain sesuai dengan karakteristik materi yang dipilih.

2. Peningkatkan keterampilan proses siswa melalui penerapan pendekatan atau metode pembelajaran hendaknya dilakukan secara berkelanjutan agar siswa dapat memiliki keterampilan proses siswa yang baik.

3. Penelitian lebih lanjut dapat dilakukan terkait keterampilan proses dasar yang lain seperti keterampilan meramalkan, keterampilan menemukan hubungan, dan keterampilan lainnya terkait proses ilmiah (praktikum).

\section{Daftar Pustaka}

[1] D. Letsholo and C.D. Yandila. 2002. Process Skills in Botswana Primary School Science Lessons. Botswana: University of Botswana.

[2] Harlen, W. (1999). "Purposes and procedures for assessing science process skills." Assessment in Education, 6. 129-144.

[3] Akinbobola, A.O., and Folashade Afolabi. 2010. Analysis of Science Process Skills in West African Senior Secondary School Certificate Physics Practical Examinations in Nigeria. American-Eurasian Journal Of Scientific Research 5 (4): 234-240.

[4] Muslim. 2012. Effort to Improve Science Process Skill Student's Learning In Physics Trough Inqury Based Model. Proceeding The Second International Seminar On Science Education "Current Issues on Research and Teaching in Science Education. ISBN: 978-979-98546-4-2. 286-294.

[5] Teo Yew Mei, Grace. 2007. Promoting Science Process Skills And The Relevance Of Science 
Through Science Alive!Programme. Proceedings of The Redesigning Pedagogy: Culture, Knowledge and Understandig Conference, Singapore, on May.

[6] Foulds, William dan John Rowe. 1996. "The Enhancement of Science Process Skills In Primary Teacher Education Student." Australian Journal Of Teacher Education, Vol 21, No.1.

[7] DePorter, Bobby; Reardon, Mark; dan Nourie, Sarah Singer. 2005. Quantum Teaching: Mempraktikan Quantum Learning di Ruang Kelas. Bandung: Kaifa.

[8] Sumiyati, E. 2011. Upaya Meningkatkan Keterampilan Proses Siswa Menggunakan Model Pembelajaran Kooperatif Tipe Numberred Heads Together (NHT) Pada Topik Kelarutan dan Hasil Kali Kelarutan. Jakarta: Universitas Negeri Jakarta.

[9] Meier, Dave. 2002. The Accelarated Learning Handbook; Panduan Kreatif dan Efektif Merancang Program Pendidikan dan Pelatihan. Alih Bahasa; Rahmani Astuti. Bandung: Kaifa.

[10] R. Barsch. J. 1996. Barsch Learning Style Inventory. California: Academic Therapy Publications.

[11] Afriawan, M. 2011. Pengaruh Penerapan Pendekatan SAVI Bervisi SETS Pada Pencapaian Kompetensi Terkait Reaksi Redoks. Yogyakarta: Universitas Negeri Yogyakarta.

[12] Tek, Ong E. And Kenneth R. 2010. Acquistion of Science Process Skills Amongst Form 3 Students In Malaysian Smart and Mainstream Schools. Journal of Science And Mathematics Education In S.E. Asia. Vol.28, No.1.

[13] BNSP. 2006. Panduan Penyusunan Kurikulum Tingkat Satuan Pendidikan Jenjang Pendidikan Dasar dan Menengah. Jakarta: BNSP

[14] Arikunto, S. 2006. Penelitian Tindakan Kelas. Jakarta: PT. Bumi Aksara. 